\title{
Consistency in fruit preferences across the geographical range of the frugivorous bats Artibeus, Carollia and Sturnira (Chiroptera)
}

\author{
Lays C. Parolin ${ }^{1,2,3}$, Gledson V. Bianconi ${ }^{4,5}$ \& Sandra B. Mikich
}

\begin{abstract}
1. Laboratório de Ecologia, Embrapa Florestas, Estrada da Ribeira, Km 111, 83411-000 Colombo, PR, Brazil. (sandra.mikich@embrapa.br) 2. Universidade Estadual Paulista "Júlio de Mesquita Filho", Rua Cristovão Colombo 2265, 15054-000 São José do Rio Preto, SP, Brazil.

3. Pontifícia Universidade Católica do Paraná, Escola de Saúde e Biociências, Rua Imaculada Conceição, 1155, 80215-182 Curitiba, PR, Brazil. 4. Instituto Neotropical: Pesquisa e Conservaçāo, Rua Purus 33, 82520-750 Curitiba, PR, Brazil.

5. Instituto Federal do Paraná, Campus Pinhais, Rua Humberto de Alencar Castelo Branco, 1575, 83330-200 Pinhais, PR, Brazil.
\end{abstract}

Received 02 February 2016

Accepted 23 May 2016

DOI: $10.1590 / 1678-4766 e 2016010$

\begin{abstract}
The frugivorous phyllostomid bat genera Artibeus, Carollia and Sturnira are important seed dispersers in the Neotropics, and exhibit supposed preferences for fruits of the genus Ficus, Piper and Solanum, respectively. We performed a quantified literature review to test the hypothesis that interactions with plants are consistent throughout the bats' geographic ranges. Through an extensive literature review we obtained a total of 4,448 records of fruit consumption from 180 publications. To test which fruits were most frequently consumed across the Neotropical region and in each of its component countries these data were organized by bat species and country. In general, considering the 176 botanical genera eaten by these bats, the results showed a high consumption frequency of Ficus (24.0\%) by Artibeus, Piper (38.7\%) by Carollia and Solanum (31.0\%) by Sturnira. Additionally, our findings support the hypothesis of diet consistency throughout the geographic range of these genera. We suggest that this consistency is related to the wide distribution of the study groups (both bats and plants), the phenology of the zoochoric species consumed, the spatial fidelity of bats and the foraging patterns of the different bat species.
\end{abstract}

KEYWORDS. Diet, frugivory, fruit phenology, geographic distribution, Phyllostomidae.

RESUMO. Consistência na preferência de frutos na extensão geográfica de morcegos frugívoros Artibeus, Carollia and Sturnira (Chiroptera). Os filostomídeos frugívoros Artibeus, Carollia e Sturnira são importantes dispersores de sementes na região Neotropical, se destacando por possuírem uma suposta preferência por frutos dos gêneros Ficus, Piper e Solanum, respectivamente. Nós realizamos uma metanálise para testar a hipótese de que as interações entre esses morcegos e plantas são consistentes ao longo de toda sua distribuição geográfica. Por meio de uma extensa revisão bibliográfica, foram compilados 4.448 registros de consumo de frutos provenientes de 180 publicações. Estes dados foram organizados por espécie de morcego e país, testando quais gêneros de frutos foram mais frequentes na região neotropical como um todo e em cada um dos seus países componentes. Num panorama geral, os resultados demonstraram alta frequência no consumo de Ficus (24,0\%) por Artibeus, Piper (38,7\%) por Carollia e Solanum (31,0\%) por Sturnira, considerando 176 gêneros botânicos citados. O estudo corrobora, assim, a hipótese da consistência da dieta desses morcegos ao longo de toda a sua distribuição geográfica, sendo esta relacionada à ampla distribuição dos grupos (morcegos e plantas) envolvidos, à fenologia das espécies zoocóricas consumidas e à fidelidade espacial dos morcegos, esta, por sua vez, moldada pela capacidade de voo das diferentes espécies.

PALAVRAS-CHAVE. Dieta, distribuição geográfica, fenologia, frugivoria, Phyllostomidae.

The family Phyllostomidae comprises 160 species that are widely distributed in the Neotropics, with 34 genera and approximately 120 species recorded as frugivorous and/ or nectivorous (SIMMONS, 2005; GARDNER, 2008). Members of this family are noted for their ecological functions, acting as controllers of insect populations, predators of small vertebrates and especially pollinators and seed dispersers (e.g. Fleming, 1988).

Since the 1930s frugivorous phyllostomids have been recognized as one of the most efficient mammalian seed dispersers in tropical forests (RIDLEY, 1930). These animals feed on ripe fruit and do not generally destroy the seeds, passing them intact through the digestive system, defecating in flight (CHARLES-DominiQue, 1991; Dumont, 2003), which results in a widely spread seed dispersal.

Artibeus Leach, 1821, Carollia Gray, 1838 and Sturnira Gray, 1842, are among the most abundant and diverse bat genera in the Americas (KALKO \& HANDLEY, 2001; GARDNER, 2008). They have great ecological importance due to their dispersal of pioneer plants (FLEMING, 1988; HENRY \& JOUARD, 2007) and according to several authors (e.g. FLEMING, 1988; KALKO et al., 1996; WENDELN et al., 2000; MiKiCH, 2002; Mello et al., 2008; ANDRADE et al., 2013) predominantly consume fruits of Ficus L. (Moraceae), Piper L. (Piperaceae) and Solanum L. (Solanaceae), respectively. Along this same line of reasoning, studies by MIKICH 
et al. (2003) and BIANCONI et al. (2007) addressed the use of smell in finding food, and showed positive results in the attraction of the genera Carollia and Artibeus with the provision of essential oils extracted from Piper and Ficus fruits. The results proved so effective that it was possible to propose such essential oils as a tool for the recovery of degraded areas, due to the associated increase in seed rain in these locations. However, monitoring the recruitment of seedlings is needed to evaluate the efficiency of the method (see ReID \& Holl, 2013).

The preference of Artibeus, Carollia and Sturnira for Ficus, Piper and Solanum fruits, respectively, is commonly cited and a recent study (ANDRADE et al., 2013) has demonstrated these preferences by combining a literature database with field experiments. Nevertheless, how bat-plant relationships behave across the spatial distribution of these three bat genera has not been investigated. It is known, however, that the phyllostomids in question are exclusively Neotropical (GARDNER, 2008) and that the three fruit genera are spread across much of the world, with Ficus ( 800 species) and Piper (approximately 1000 species) being pantropical and Solanum (approximately 1500 species) distributed in all continents of the globe (JARAMILlo \& MANOS, 2001; SHANAHAN et al., 2001; KNAPP et al., 2004). Ficus is intraspecifically asynchronous, producing an abundance of ripe fruit in the same individual, which is generally available for only a few weeks (MorRISON, 1978). In contrast, Piper and Solanum are synchronous and provide lower amounts of fruit per night, but over a longer period (DuMONT, 2003).

The objective of the present study is to fill this gap through a quantified literature review of the interactions between these bat and plant genera throughout the Neotropics. We use these widely distributed genera to test the hypothesis of consistency of diet across the geographic range, which is associated with the broad distribution of the groups (bats and plants), the phenology of the species consumed and also the spatial fidelity of the phyllostomids.

\section{MATERIAL AND METHODS}

The study consisted of a literature review and data compilation of fruit consumption by representatives of the genera Artibeus, Carollia and Sturnira throughout their distributional range. Therefore, we performed a search in Web of Science (http://apps.webofknowledge.com) with the following keywords and combinations thereof: "Artibeus", "Carollia", "Sturnira", "Chiroptera", "bat", "diet", "fruit"”, "frugivory" and "plant". We also used information obtained from the Database OF NeOtropical Bat/Plant InTERACtions (2013), a database created in 2001 with information on dispersal and pollination by Neotropical bats.

The collected information was organized in a spreadsheet with the following entries: bat (species and/ or genus), fruit consumed (species, genus and/or family), location, country, recording method and source. Each entry of a plant species (or genus/family when species unknown) accounted for one record. Records could be based on direct observations, analysis of stomach contents and/or analysis of fecal samples.

To identify the fruit genera with a significantly greater number of consumption records for each bat genus a chisquare test was used, with a $\alpha$ significance probability of $\mathrm{P}<$ 0.05 . The same procedure was used to compare the number of records among countries. Prior analyses, all duplicate information, derived from compilations of primary data sources (i.e. review articles, studies referring to data collected and published in other sources), were excluded.

The data were first tabulated as cited in the source and the taxonomy subsequently standardized according to Simmons (2005) for bats, and following ForzzA et al. (2013) for native Brazilian plant species and THE PLANT LIST (2013) for other plant species included in the spreadsheet.

Maps were made using the political boundaries of the countries of the Neotropical region, with the distribution of the fruit genera consumed ( $c f$. JARAMILLO \& MANOS, 2001 - Piper, Knapp et al., 2004 - Solanum, Lobova et al., 2003 - Cecropia, Shanahan et al., 2001 - Ficus), which was then overlaid on that of the bat genera, following GARDNER (2008). The maps show the Wallaceana configuration of the Neotropical region (Cox, 2001). The distribution of both fruits and bats was presented at the scale of the whole country, regardless of whether their documented coverage included all or only a portion of that territory. This decision was made due to the lack of detailed information presented in most of the sources consulted. We selected only the most common fruit genera consumed by each bat genera for mapping.

\section{RESULTS}

The literature review resulted in 180 studies and 4,448 records of fruit consumption by the three bat genera. Of these, 3,243 were used in analyzes and 1,205 were excluded as they were duplicate records reported by different sources. Altogether, 176 genera from 62 botanical families were reported. A total of 22 bat species were recorded for Artibeus $(\mathrm{N}=11)$, Carollia $(\mathrm{N}=5)$ and Sturnira $(\mathrm{N}=6)$.

All three studied bats were found to consume a wide range of fruit genera and families: Artibeus consumed fruit from 51 families, 135 genera and 268 species, Carollia from 44 families, 78 genera and 220 species, and Sturnira from 32 families, 54 genera and 165 species. Nevertheless, almost $24.0 \%(\mathrm{n}=376)$ of all records for Artibeus were represented by Ficus $\left(\chi^{2}=292.41, \mathrm{P}<0.00001\right)$. The same was true for $38.7 \%(\mathrm{n}=425)$ of all records for Carollia, which belonged to Piper $\left(\chi^{2}=1183.63, \mathrm{P}<0.00001\right)$ and $31.0 \%(\mathrm{n}=162)$ of all records for Sturnira, which were represented by Solanum $\left(\chi^{2}=247.17, \mathrm{P}<0.00001\right)$. Cecropia Loefl. (Urticaceae) was the second (Artibeus) or third (Carollia and Sturnira) most frequently consumed fruit genus by these bats (Fig. 1).

When the geographic distribution of these four fruit genera was superimposed on that of the three bat general (Fig. 2), considerable overlap was found, although bats do not occupy all Neotropical areas where these fruit are available.

When the data were analyzed by country, Ficus was 


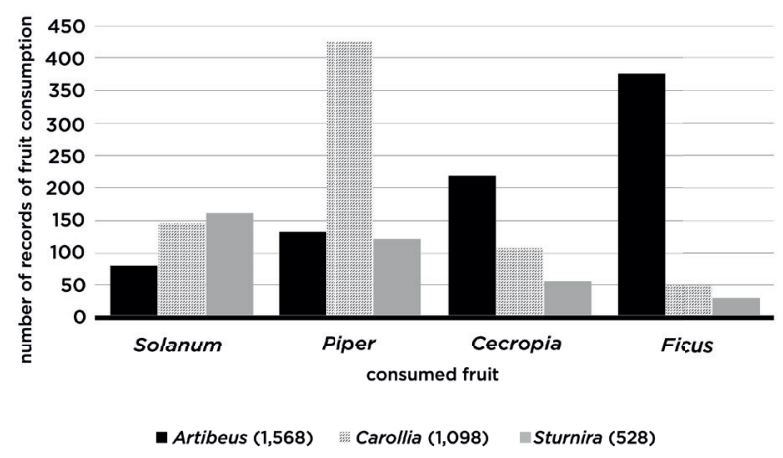

Fig. 1. Number of records for the four fruit genera most frequently consumed by Artibeus, Carollia and Sturnira (total number of records for each bat species) based on literature review.

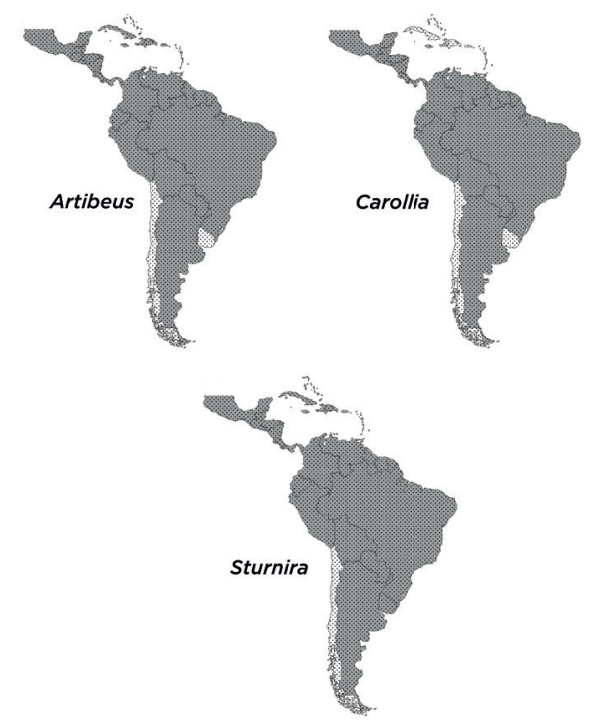

Fig. 2. Distribution of three bat genera (Artibeus, Carollia and Sturnira - solid gray) and the four most frequent plant genera (Cecropia, Ficus, Piper and Solanum - dotted pattern) in their diet in the Neotropical region. Sources: bat distribution follows GARDNER (2008); plant distribution follows JARAMILLO \& MANOS (2001) for Piper; KNAPP et al. (2004) for Solanum, Lobova et al. (2003) for Cecropia; Shanahan et al. (2001) for Ficus.

the most consumed fruit species by Artibeus in Bolivia, Brazil, Costa Rica, Cuba, Guatemala, Mexico and Panama. However, when compared to the other fruit genera consumed the difference was significant only in countries with a large total number of fruit consumption records. This was true for Brazil ( $\mathrm{n}=924)$, Costa Rica $(\mathrm{n}=638)$, Panama $(\mathrm{n}=304)$ and Mexico $(\mathrm{n}=205)$, but not for French Guiana $(\mathrm{n}=556)$, where the consumption of fruits from the genus Cecropia predominated (Tab. I).

Piper was the genus most consumed by Carollia in Brazil, Costa Rica, Guatemala, Guyana, Mexico, Panama, Peru, Bolivia and Mexico, with the latter two only being non-significant (Tab. I). Solanum was the most consumed fruit genus by Sturnira in Argentina, Bolivia, Brazil, French Guiana, Mexico and Peru, whereas Piper was more frequently consumed in Costa Rica and Guatemala (Tab. I).
The majority of the most intensively sampled countries showed more records of the preferred plant genera, while those countries with fewer records and publications did not show the pattern observed for the Neotropics (Fig. 1 and Tab. I). Among the latter (all with $<5$ studies) were the French Antilles, Colombia, El Salvador, Guyana, Jamaica, Puerto Rico, Trinidad and Tobago, Uruguay and Venezuela (Tab. I).

\section{DISCUSSION}

Our findings confirm consistency in the consumption of Ficus, Piper and Solanum fruits throughout the Neotropical range of Artibeus, Carollia and Sturnira, respectively. However, in some countries, this pattern was not evident, probably due to the small number of studies on the diet of bats conducted there, as in most regions with a large sampling effort (with the exception of French Guiana) the pattern was consistent.

The exclusively Neotropical pioneer genus Cecropia (LoBova et al., 2003) was among the four most commonly consumed genera by the bats, particularly Artibeus. This is probably related to its phylogenetic proximity with the family Moraceae (ZHANG et al., 2011), the family that includes Ficus. Other genera appeared to be more frequently consumed within certain regions, such as Vismia Vand. (Hypericaceae) in Brazil and Panama, Spondias L. (Anacardiaceae) in Cuba, El Salvador and Panama, and Philodendron Schott (Araceae) in French Guiana.

Some of the species (Carica papaya L. and Syzygium jambos (L.) Alston, for example) consumed by these bats are exotic and their consumption and subsequent dispersion may impact native flora (MINOR \& GARDNER, 2011; VoIGT et al., 2011). Bats seem to respond positively to fruit availability (LoBova et al., 2009), reinforcing the need for planning in both urban and rural areas to protect native flora from invasions (BARROs et al., 2006).

Frugivory is a facultative mutualistic interaction as it benefits the consumer (which gains energy and nutrients) and the plant, which has its propagules transported far from the parent plant (Boucher et al., 1982). According to some authors, species with broad geographic ranges experience different pressures depending on their location, thereby establishing different interactions and developing geographically distinct specializations (THOMPSON, 2005; Mello et al., 2011). However, in the case of the bats studied, it is clear that regardless of the climatic, geomorphologic, and floristic differences found throughout the Neotropics and all the plant diversity available $(90,000$ Neotropical plant species according to GENTRY, 1982), the consumption of some fruit genera remained relatively unchanged. In equatorial Mexico, for example, these bats fed mainly on Ficus, Piper and Solanum (OlEa-WaGNer et al., 2007), the same pattern observed in Argentina, a country with a subtropical climate (SÁNCHEZ et al., 2012).

The consistency found in the diet of the studied phyllostomids throughout their distribution suggests a strong interaction with some food plants. One of the factors 
Tab. I. Consumption of fruit from different plant genera by Artibeus, Carollia and Sturnira in different countries of the Neotropical region, based on literature review $\left[\mathrm{N}_{\mathrm{stu}}\right.$, number of studies revised for each country; $\mathrm{N}_{\text {rec }}$, total number of records to that particular genus; *, indicates that the number of records for a given genus (shown in parentheses) is significantly greater than the others obtained for the same country $(\mathrm{P}<0.05)]$.

\begin{tabular}{|c|c|c|c|c|c|}
\hline Country & $\mathrm{N}_{\text {stu }}$ & $\mathrm{N}_{\text {rec }}$ & Artibeus & Carollia & Sturnira \\
\hline French Antilles & 1 & 3 & $\begin{array}{c}\text { Manilkara (1) Solanum (1) } \\
\text { Terminalia }(1)\end{array}$ & - & - \\
\hline Argentina & 5 & 14 & 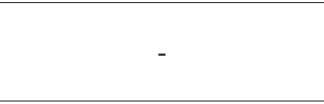 & - & $\begin{array}{c}\text { Celtis (2) } \\
\text { Piper (4) } \\
\text { Solanum (8)* }\end{array}$ \\
\hline Bolivia & 2 & 8 & $\begin{array}{l}\text { Cecropia (1) } \\
\text { Brosimum (2) } \\
\text { Ficus (2) }\end{array}$ & Piper (2) & Solanum (1) \\
\hline Brazil & 78 & 924 & $\begin{array}{l}\text { Piper (44) } \\
\text { Cecropia }(74) \\
\text { Ficus }(116)^{*}\end{array}$ & $\begin{array}{c}\text { Vismia }(20) \\
\text { Solanum }(49) \\
\text { Piper }(88)^{*} \\
\end{array}$ & $\begin{array}{c}\text { Ficus }(20) \\
\text { Piper }(56) \\
\text { Solanum }(76)^{*}\end{array}$ \\
\hline Colombia & 1 & 1 & Pilocereus (1) & - & - \\
\hline Costa Rica & 26 & 638 & $\begin{array}{c}\text { Cecropia }(25) \\
\text { Piper }(36) \\
\text { Ficus }(51)^{*}\end{array}$ & $\begin{array}{l}\text { Cecropia }(26) \\
\text { Solanum }(35) \\
\text { Piper }(171)^{*}\end{array}$ & $\begin{array}{c}\text { Cecropia }(8) \\
\text { Solanum }(20) \\
\text { Piper }(34)^{*}\end{array}$ \\
\hline Cuba & 1 & 33 & $\begin{array}{l}\text { Spondias (2) } \\
\text { Syzygium (2) } \\
\text { Ficus }(3) \\
\end{array}$ & 工 & ב \\
\hline El Salvador & 1 & 4 & $\begin{array}{c}\text { Ficus (2) } \\
\text { Spondias (2) }\end{array}$ & - & - \\
\hline Ecuador & 1 & 6 & - & $\begin{array}{c}\text { Ficus }(1) \\
\text { Cecropia }(2) \\
\text { Piper }(2)\end{array}$ & - \\
\hline Guatemala & 1 & 61 & $\begin{array}{l}\text { Cecropia (4) } \\
\text { Piper (8) } \\
\text { Ficus }(9) \\
\end{array}$ & $\begin{array}{l}\text { Cecropia (3) } \\
\text { Solanum (6) } \\
\text { Piper }(16)^{*}\end{array}$ & $\begin{array}{c}\text { Cecropia }(1) \\
\text { Solanum }(4) \\
\text { Piper }(6)\end{array}$ \\
\hline Guyana & 1 & 4 & - & $\begin{array}{l}\text { Solanum (1) } \\
\text { Vismia (1) }\end{array}$ & $\begin{array}{l}\text { Solanum }(1) \\
\text { Vismia }(1)\end{array}$ \\
\hline French Guiana & 17 & 556 & $\begin{array}{c}\text { Andira }(10) \\
\text { Ficus }(41) \\
\text { Cecropia }(66)^{*}\end{array}$ & $\begin{array}{l}\text { Cecropia }(28) \\
\text { Solanum }(37) \\
\text { Piper }(57)^{*}\end{array}$ & $\begin{array}{c}\text { Cecropia }(20) \\
\text { Philodendron }(21) \\
\text { Solanum }(31)^{*}\end{array}$ \\
\hline Jamaica & 1 & 2 & $\begin{array}{c}\text { Andira (1) } \\
\text { Brosimum (1) }\end{array}$ & - & - \\
\hline Mexico & 17 & 205 & $\begin{array}{c}\text { Cecropia }(12) \\
\text { Piper }(23) \\
\text { Ficus }(35)^{*}\end{array}$ & $\begin{array}{c}\text { Ficus }(3) \\
\text { Cecropia }(5) \\
\text { Piper }(7) \\
\end{array}$ & $\begin{array}{l}\text { Cecropia }(4) \\
\text { Piper }(6) \\
\text { Solanum }(7) \\
\end{array}$ \\
\hline Panama & 13 & 304 & $\begin{array}{l}\text { Cecropia }(12) \\
\text { Spondias }(22) \\
\text { Ficus }(51)^{*}\end{array}$ & $\begin{array}{l}\text { Vismia }(7) \\
\text { Solanum }(8) \\
\text { Piper }(59)^{*}\end{array}$ & Cecropia (1) \\
\hline Peru & 5 & 139 & $\begin{array}{c}\text { Piper }(7) \\
\text { Cecropia }(15)^{*}\end{array}$ & $\begin{array}{l}\text { Solanum }(7) \\
\text { Cecropia }(17) \\
\text { Piper }(21)^{*}\end{array}$ & $\begin{array}{c}\text { Piper (1) } \\
\text { Cecropia (2) } \\
\text { Solanum (3) } \\
\end{array}$ \\
\hline Porto Rico & 3 & 15 & $\begin{array}{c}\text { Manilkara }(2) \\
\text { Cecropia }(2)\end{array}$ & 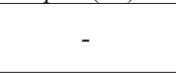 & 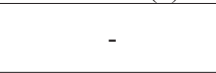 \\
\hline Trinidad and Tobago & 3 & 237 & $\begin{array}{l}\text { Manilkara }(8) \\
\text { Syzygium }(12)\end{array}$ & $\begin{array}{l}\text { Manilkara (4) } \\
\text { Syzygium (6) }\end{array}$ & - \\
\hline Uruguay & 1 & 2 & - & - & $\begin{array}{c}\text { Eugenia (1) } \\
\text { Passiflora (1) }\end{array}$ \\
\hline Venezuela & 4 & 42 & $\begin{array}{l}\text { Anacardium (4) } \\
\text { Syzygium (4) }\end{array}$ & Vismia (1) & $\begin{array}{c}\text { Solanum (1) } \\
\text { Saurauia (1) } \\
\text { Calycolpus (1) }\end{array}$ \\
\hline
\end{tabular}

contributing to this interaction may be the seed dispersal syndrome. In fact, the three most consumed fruit genera all have several species that fall into the bat-dispersal syndrome ( $c f$. VAN DER PIJL, 1957) as their attributes are believed to facilitate the location and consumption by bats (LASKA \& Schmidt, 1986; Thies et al., 1998). Nevertheless, as shown by this study and ANDRADE et al. (2013), diet segregation at genus and species level suggests that other factors (chemical, behavioural, etc.) are acting as well.

A rarely discussed but interesting and relevant factor is the spatial fidelity of bats, which is shaped by the phenology and occurrence of their most consumed fruits (BiANCONI et al., 2006; FARIA \& BAUMGARTEN, 2007). For example, Carollia spp. exhibit greater constancy in the use of certain habitats compared with Artibeus, supposedly due to the spatial and temporal predictability of the Piper fruits (see above). Bat morphology may also be related to these foraging patterns, as due to the relatively small size of Carollia spp. (14-25 g) their flight capacity is more restricted to closed environments (STOCKWELL, 2001). The opposite occurs with Artibeus spp., which does not remain long in the same environment, probably due to the low abundance 
and asynchronous behavior of Ficus (BIANCONI et al., 2006). This pattern may also be related to their larger size (55-70 g) and greater potential for flight, which enables them to travel great distances in a single night in search of food (Stockwell, 2001; Dumont, 2003).

The significant consumption of Moraceae fruits - mainly figs - by Artibeus spp. is widely supported by previous studies (e.g. Morrison, 1978; BonACCORSO, 1979; HANDLEY et al., 1991). Ficus is a genus of canopy trees, widely distributed in the Neotropics from Mexico to Paraguay (BANACK et al., 2002), whose representatives are intraspecifically asynchronous, but present a "boom" of syconia maturation within the canopy, which generally contains thousands of fruits (MorRISON, 1978). Such an abundance of resources attracts consumers from various groups, including birds, primates and other mammals (see ShanAHAn et al., 2001 for a review). For this reason, figs are considered keystone species for frugivores (TERBORGH, 1986). Some authors relate the elevated consumption of Ficus by bats to: position occupied by these trees in the forest stratum (BONACCORSO, 1979), nutritional composition (WeNDELn et al., 2000; Dumont, 2003), or opportunistic behavior related to the abundance of this resource (Heithaus et al., 1975; Bonaccorso, 1979; Mello \& Passos, 2008). Although this last factor should contribute to the maintenance of the Artibeus-Ficus relationship, selection for fruit of this genus occurs even when their abundance is lower than that of other fruits (Morrison, 1978; PAROLIN et al., 2015).

Piperaceae and bats of the genus Carollia possess a high affinity and the literature abounds with records of Piper fruit consumption by these phyllostomids (e.g. BONACCORSO, 1979; Fleming, 1988; Thies \& Kalko, 2004; SÁncheZ et al., 2012; the present study), with studies even proposing coevolution between these genera (THIES \& KALKO, 2004). The genus Piper comprises pioneer plants, common to degraded areas in the Neotropics (Lobova et al., 2009). Their green smelly spike-shaped infructescences are typical examples of bat fruits (VAN DER PIJL, 1957). Each individual plant produces few ripe fruits per night (DUMONT, 2003, steady state pattern according to SNOw, 1965), over relatively extended periods (usually two or three months) (FLEMING, 1988). Nevertheless, different Piper species exhibit low phenological overlap allowing them to share dispersers and feed them all year round (FLEMING, 1985). All these traits are believed to be important in maintaining Carollia spp. as the main consumers and dispersers of Piper spp. (THIES \& KALKO, 2004).

The genus Sturnira also appears to primarily consume steady state fruits. Although several studies show their preferential consumption of Solanum (e.g. GianninI, 1999; Mello et al., 2008; Lobova et al., 2009; but see Miкich, 2002), there are also several reports of interactions with the fruits of Piper (e.g. GiANNINI, 1999; SÁNCHEZ et al., 2012). In fact, although we found that the Solanum was the genus most frequently consumed by Sturnira, the consumption of Piper fruits was also significant.
In the most intensively sampled localities the majority of fruit consumption by Artibeus, Carollia and Sturnira was recorded in the genera Ficus, Piper and Solanum. This finding confirms the spatial consistency of these supposed preferences. There are several non-mutually exclusive explanations for this phenomenon, including the broad distribution of the groups, the way these resources are offered and the spatial and temporal patterns in habitat use by bats, all of which favor these mutualistic encounters. Our results also indicate the need for a greater effort to fill knowledge gaps in countries where the diet of these frugivorous bats remains poorly sampled.

Acknowledgments. This paper is part of the dissertation of the first author. We thank Empresa Brasileira de Pesquisa Agropecuária (EMBRAPA) and Embrapa Florestas for logistical support; Coordenação de Aperfeiçoamento de Pessoal de Nível Superior (CAPES) for a master's scholarship to LCP.

\section{REFERENCES}

Andrade, T. Y.; Thies, W.; Rogeri, P. K.; Kalko, E. K. V. \& Mello, M. A. R. 2013. Hierarchical fruit selection by Neotropical leaf-nosed bats (Chiroptera: Phyllostomidae). Journal of Mammalogy 94:1094-1101.

Banack, S. A.; Horn, M. H.; \& Gawlick, A. 2002. Disperser-vs. establishment-limited distribution of a riparian fig tree (Ficus insipida) in a Costa Rican tropical rain Forest. Biotropica 34:232-243.

Barros, R. S. M.; Bisaggio, E. L. \& Borges, R. C. 2006. Morcegos (Mammalia, Chiroptera) em fragmentos florestais urbanos no município de Juiz de Fora, Minas Gerais, sudeste do Brasil. Biota Neotropica 6:1-6.

Bianconi, G.V.; Mikich, S. B. \& Pedro, W. A. 2006. Movements of bats (Mammalia, Chiroptera) in Atlantic Forest remnants in southern Brazil. Revista Brasileira de Zoologia 23:1199-1206.

Bianconi, G. V.; Mikich, S. B.; Teixeira, S. D. \& Maia, B. H. L. N. S. 2007. Attraction of fruit-eating bats with essential oils of fruits: a potential tool for forest restoration. Biotropica 39:136-140.

BonacCorso, F. J. 1979. Foraging and reproductive ecology in a Panamanian bat community. Bulletin of the Florida State Museum Biological Sciences 24:359-408.

Boucher, D. H.; James, S, \& Keeler, K. H. 1982. The Ecology of Mutualism. Annual Review of Ecology, Evolution and Systematics 13:315-347.

Charles-DominiQue, P. 1991. Feeding strategy and activity budget of the frugivorous bat Carollia perspicillata (Chiroptera: Phyllostomidae) in French Guiana. Journal of Tropical Ecology 7:243-256.

Cox, C. B. 2001. The biogeographic regions reconsidered. Journal of Biogeography 28:511-523.

Database of Neotropical Bat/Plant Interactions. 2013. Available at <http://www.nybg.org/botany/tlobova/mori/batsplants/database/ dbase_main.htm>. Accessed on 30 December 2013.

Dumont, E. R. 2003. Bats and Fruit: An ecomorphological approach. In: Kunz, T. H. \& Fenton, B. eds. Bat Ecology. Chicago, University of Chicago Press, p. 398-429.

FARIA, D. \& Baumgarten, J. 2007. Shade cacao plantations (Theobroma cacao) and bat conservation in southern Bahia, Brazil. Biodiversity and Conservation 16:291-312.

Fleming, T. H. 1985. Coexistence of five sympatric Piper (Piperaceae) species in a Costa Rican dry forest. Ecology 66:688-700.

1988. The short-tailed fruit bat: A study in plant-animal interactions. Chicago, University Chicago Press. 380p.

Forzza, R. C.; Leitman, P. M.; Costa, A. F.; Carvalho, Jr A. A.; Peixoto, A. L.; Walter, B. M. T.; Bicudo, C.; Zappi, D.; Costa, D. P.; Lleras, E.; Martinelli, G.; Lima, H. C.; Prado, J.; Stehmann, J. R.; Baumgratz, J. F. A.; Pirani, J. R.; Sylvestre, L.; Maia, L. C.; Lohmann, L. G.; Queiroz, L. P.; Silveira, M.; Coelho, M. N.; Mamede, M. C.; Bastos, 
M. N. C.; Morim, M. P.; Barbosa, M. R.; Menezes, M.; Hopkins, M.; Secco, R.; Cavalcanti, T. B. \& Souza, V. C. 2013. Lista de Espécies da Flora do Brasil. Available at <http://floradobrasil.jbrj. gov.br/2013>. Accessed on 30 December 2013.

GARDNER, A. L. 2008. Mammals of South America, Volume 1: Marsupials, Xenarthrans, Shrews, and Bats. Chicago, London, University of Chicago Press. 690p.

Gentry, A. H. 1982. Neotropical floristic diversity: phytogeographical connections between Central and South America, pleistocene climatic fluctuations, or an accident of the andean orogeny? Annals of the Missouri Botanical Garden 69:557-593.

GiANNINI, N. P. 1999. Selection of diets and elevation by sympatric species of Sturnira in an Andean rainforest. Journal of Mammalogy 80:11861195.

Handley, Jr C. O.; Wilson, D. E. \& Gardner, A. L. 1991. Demography and natural history of the common fruit bat Artibeus jamaicensis on Barro Colorado Island, Panamá. Washington, Smithsonian Institution Press. 173p.

Heithaus, E. R.; Fleming, T. H. \& Opler, P. A. 1975. Foraging patterns and resource utilization in seven species of bats in a seasonal tropical forest. Ecology 56:841-854.

Henry, M. \& Jouard, S. 2007. Effect of bat exclusion on patterns of seed rain in tropical rainforest in French Guiana. Biotropica 39:510-518.

Jaramillo, M. A. \& Manos, P. S. 2001. Phylogeny and patterns of floral diversity in the genus Piper (Piperaceae). American Journal of Botany 88:706-716.

Kalko, E. K. V. \& Handley, JR C. O. 2001. Neotropical bats in the canopy: diversity, community structure and implications for conservation strategies. Plant Ecology 153:319-333.

Kalko, E. K. V.; Handley, Jr C. O. \& Handley, D. 1996. Organization, diversity and long-term dynamics of a Neotropical bat community. In: Cody, M. L. \& Smallwood, J. A. eds. Long-term studies of vertebrate communities. New York, Academic Press, p. 503-553.

KnApr, S.; Bohs, L.; NeE, M. \& Spooner, D. M. 2004. Solanaceae: a model for linking genomics and biodiversity. Comparative and Functional Genomics 5:285-291.

LASKA, M. \& SCHMIDT, U. 1986. Untersuchungen zur olfaktorischen orientierung bei der Brillenblattnase, Carollia perspicillata (Chiroptera). Zeitschrift für Säugetierkunde 51:129-138.

Lobova, T. A.; Geiselman, C. K. \& Mori, A. S. 2009. Seed dispersal by bats in the Neotropics. New York, New York Botanical Garden Press. 465p.

Lobova, T. A.; Mori, S. A.; Blanchard, F.; Peckham, H. \& CharlesDominiQue. P. 2003. Cecropia as a food resource for bats in French Guiana and the significance of fruit structure in seed dispersal and longevity. American Journal of Botany 90:388-403.

Mello, M. A. R.; Kalko, E. K. V. \& Silva, W. R. 2008. Movements of the bat Sturnira lilium and its role as a seed disperser of Solanaceae in the Brazilian Atlantic Forest. Journal of Tropical Ecology 24:225-228.

Mello, M. A. R. \& Passos, F. C. 2008. Frugivoria em morcegos brasileiros. In: Pacheco, S.; Marques, R. V. \& Esbérard, C. E. L. eds. Morcegos do Brasil: biologia, sistemática, ecologia e conservação. Porto Alegre, Editora Armazém Digital. 568p.

Mello, M. A. R.; Marquitti, F. M. D.; Guimarães, Jr P. R.; Kalko, E. K. V.; Jordano, P. \& Aguiar, M. A. M. 2011. The missing part of seed dispersal networks: structure and robustness of bat-fruit interactions. Plos One 6:1-10.

Mikich, S. B. 2002. A dieta dos morcegos frugívoros (Mammalia, Chiroptera, Phyllostomidae) de um pequeno remanescente de Floresta Estacional Semidecidual do sul do Brasil. Revista Brasileira de Zoologia 19:239249.
Mikich, S. B.; Bianconi, G. V.; Maia, B. H. L. N. S. \& Teixeira, S. D. 2003. Attraction of the fruit-eating bat Carollia perspicillata to Piper gaudichaudianum essential oil. Journal of Chemical Ecology 29:2379-2383.

Minor, E. S. \& GARDNER, R. H. 2011. Landscape connectivity and seed dispersal characteristics inform the best management strategy for exotic plants. Ecological Applications 21:739-749.

Morrison, D. W. 1978. Influence of habitat on the foraging distances of the fruit bat, Artibeus jamaicensis. Journal of Mammalogy 59:622-624.

Olea-Wagner, A.; Lorenzo, C.; Naranjo, E.; Ortiz, D. \& LeOnPaniagua, L. 2007. Diversity of fruits consumed by three species of bats (Chiroptera: Phyllostomidae) in the Lacandona rainforest, Chiapas, México. Revista Mexicana de Biodiversidad 78:191-200.

Parolin, L. C.; Mikich, S. B. \& Bianconi, G. V. 2015. Olfaction in the fruit-eating bats Artibeus lituratus and Carollia perspicillata: an experimental analysis. Anais da Academia Brasileira de Ciências 87:2047-2053.

ReID, J. L. \& HolL, K. D. 2013. Arrival $\neq$ Survival. Restoration Ecology 21:153-155.

RiDley, H. N. 1930. The dispersal of plants throughout the world. Ashford, L. Reeve and Co., Ltd. 774p.

SÁnchez, M. A.; Giannini, N. P. \& Barquez, R. M. 2012. Bat frugivory in two subtropical rain forests of Northern Argentina: Testing hypotheses of fruit selection in the Neotropics. Mammalian Biology 77:22-31.

Shanahan, M.; So, S.; Compton, S. G. \& Corlett, R. 2001. Fig-eating by vertebrate frugivores: a global review. Biological Reviews 77:529-572.

Simmons, N. B. 2005. Order Chiroptera, p. 312-529. In: Wilson, D. E. \& REEDER, D. M. eds. Mammal species of the world: A taxonomic and geographic reference. Baltimore, Johns Hopkins University Press. 2142p.

SNOw, D. W. 1965. A possible selective factor in the evolution of fruiting seasons in tropical forest. Oikos 15:274-281.

StockWELl, E. F. 2001. Morphology and flight manoeuvrability in New World leaf-nosed bats (Chiroptera: Phyllostomidae). Journal of Zoology 254:505-514.

Terborgh, J. 1986. Community aspects of frugivory in tropical forests. In: Estrada, A. \& Fleming, T. H. eds. Frugivores and seed dispersal. Dordrecht, W. Junk Publishers, p. 371-384.

The Plant List. 2013. Available at <http://www.theplantlist.org $>$. Accessed on 23 October 2013.

Thies, W. \& Kalko, E. K. V. 2004. Phenology of neotropical pepper plants (Piperaceae) and their association with their main dispersers, two short-tailed fruit bats, Carollia perspicillata and C. castanea (Phyllostomidae). Oikos 104:362-376.

Thies, W.; Kalko, E. K. V. \& Schnitzler, H. U. 1998. The roles of echolocation and olfaction in two Neotropical fruit-eating bats, Carollia perspicillata and C. castanea, feeding on Piper. Behavioral Ecology and Sociobiology 42:397-409.

Thompson, J. N. 2005. The geographic mosaic of coevolution. Chicago, University of Chicago Press. 400p.

VAN DER PIJL, L. 1957. The dispersal of plants by bats (Chiropterochory). Acta Botanica Neerlandica 6:291-315.

Voigt, F. A.; FARwiG, N. \& Johnson, S. D. 2011. Interactions between the invasive tree Melia azedarach (Meliaceae) and native frugivores in South Africa. Journal of Tropical Ecology 27:355-363.

Wendeln, M. C.; Runkle, J. R. \& Kalko, E. K. V. 2000. Nutritional values of 14 fig species and bat feeding preferences in Panama. Biotropica 32:489-501.

ZHANG. S.; Soltis, D. E.; YAnG, Y.; LI, D. \& YI, T. 2011. Multi-gene analysis provides a well-supported phylogeny of Rosales. Molecular Phylogenetics and Evolution 60:21-28. 